\title{
PNEUMATIKUS MESTERSÉGES IZOM ÁLTAL MŰKÖDTETETT REHABILTÁCIÓS ESZKÖZÖK TERVEZÉSE ÉS KIVITELEZÉSE
}

\author{
Sárosi József - Csikós Sándor - Szabó Zénó - Bálint Ádám - Gergely Attila - \\ Dobó Franciska
}

\begin{abstract}
Absztrakt: A pneumatikus mesterséges izom (PMI) egy süritett levegővel müködö, összehúzódókitáguló eszköz. A sugárirányú tágulással egyidejüleg a membrán tengelyirányban összehúzódik, ezáltal húzóerôt fejt ki a terhelésén. Az általa generált erỏ és mozgás egyenes vonalú és egyirányú. Mivel a PMI egyszeres müködésü (csak húzóeröt képes kifejteni), a kétirányú mozgás megvalósításához két izom szükséges - a valóságos izmokhoz hasonlóan. Az egyik mozgatja a terhet, mig a másik a célpozícióban fékként müködik. Ellenkező irányú mozgásnál az izmok szerepet cserélnek. Ezeket a szembekapcsolt izmokat antagonisztikus izompárnak, a mozgató izmot flexornak vagy agonistnak, a fékezö izmot extensornak vagy antagonistnak is nevezzük. Ezen elrendezéssel lineáris és forgó mozgás is megvalósitható. A PMI-k jellemzöje továbbá, hogy egyszerü felépitésüek, könnyüek, eredendően rugalmasak, egyszerü üzemvitelüek, nagy sebességre képesek, nagy a teljesítmény/tömeg és teljesítmény/térfogat arányuk, olcsóak és nagy üzem-, robbanás- és tüzbiztonságúak. E munkánkban általunk megtervezett és kivitelezett, PMI-ket tartalmazó rehabilitációs eszközöket ismertetünk.
\end{abstract}

\begin{abstract}
Abstarct: Pneumatic artificial muscle (PAM) is an actuator, which converts pneumatic energy into mechanical form by transferring the pressure applied on the inner surface of its bladder into the shortening tension. PAMs' source of energy comes from pressurized gas, usually air. There are a lot of advantages of pneumatic artificial muscles like the high strength, good power-weight ratio, low price, little maintenance needed, great compliance, compactness, inherent safety and usage in rough environments. As PMAs are one-way acting, two are needed to generate bidirectional motion: as one of them moves the load, the other one will act as a brake to stop the load at its desired position. To move the load in the opposite direction the muscles change function. This opposite connection of the muscles to the load is generally referred to as an antagonistic set-up: the driving muscle is called the flexor or agonist, while the brake muscle is referred to as the extensor or antagonist. The antagonistic coupling can be used for either linear or rotational motion.
\end{abstract}

Kulcsszavak: pneumatikus mesterséges izom, Fluidic Muscle, rehabilitációs eszköz

Keywords: pneumatic artificial muscle, Fluidic Muscle, rehabilitation device

\section{Bevezetés}

A kontrakciós pneumatikus munkahengereket a szakirodalmak többnyire pneumatikus mesterséges izmoknak vagy pneumatikus izom végrehajtóknak nevezik. A pneumatikus mellett további végrehajtótípusok is ismertek, melyek mesterséges izomként használhatók: alakmemória ötvözet végrehajtók, elektrosztatikus végrehajtók, magnetostrikciós végrehajtók, piezoelektromos végrehajtók, valamint polimerikus végrehajtók. A PMI-k az orvostudomány területén betöltött szerepükön (pl. müvégtag mozgatása, ismétlödő feladatok elvégzésére szolgáló rehabilitációs eszközök mozgatója) túl egyre fontosabb szerepet játszanak a robotika (pl. ugráló és sétáló robotok), valamint ipari 
alkalmazások (pl. lyukasztógép, papír- és fóliatekercselö, emelöszerkezet, illetve vibrációs tölcsér) végrehajtó elemeként (Sárosi, 2013).

A kontrakciós pneumatikus munkahenger alapötlete az orosz Garasiev nevéhez füzödik és egészen az 1930-as évekig nyúlik vissza, azonban a kor akkori technológiai szintje csak korlátozott alkalmazást tett lehetővé Az első igazi áttörés Joseph L. McKibben nevéhez füződik az 1950-es években, aki - miután vizsgálta az analógiát a pneumatikus és a természetes izmok között - az általa tervezett és a róla elnevezett pneumatikus izmot alkalmazta rehabilitációs eszközben a paralizisben szenvedők mozgásának megkönnyítésére. A pneumatikus mesterséges izmok számos változatát kidolgozták mára. Így a legelterjedtebb, McKibben típus mellett a szakirodalmak további pneumatikus izmokat is megemlitenek: Yarlott, ROMAC, Kukolj, Morin, Baldwin, Pleated PAM, Rubbertuator, stb. Gyakran a müködésükre utaló elnevezésekkel találkozunk: Pneumatic Muscle Actuator, Fluid Actuator, Fluid-Driven Tension Actuator, Axially Contractible Actuator és Tension Actuator (Daerden. 1999; Daerden és Lefeber 2002), valamint Fluidic Muscle (Festo, 2005).

E tanulmányban - mely folytatása Sárosi és Gyeviki (2010) munkájának ismertetésre kerülnek pneumatikus mesterséges izmok által müködtetett rehabilitációs eszközök, melyeket hallgatók bevonásával fejlesztettünk ki.

\section{Pneumatikus mesterséges izom által támogatott kézterápiás eszköz}

E rehabilitációs eszköz kifejlesztése Koeneman et al. (2004) munkája alapján történt, akik a csukló és ujjak terápiás kezelésére szolgáló, PMI-ket magába foglaló eszközt ismertetnek ( 1 . ábra). A tervezés fö célja egy olyan eszköz létrehozása volt, amely az alkalmazott idegkutatási tanulmányok legújabb eredményeit felhasználva agyvérzést túlélt betegek kézfunkciójának javítására szolgál. Az elnevezéssel (Mentor ${ }^{\mathrm{TM}}$ ) is biztatni akarják a betegeket, hogy segítsenek önmagukon. 
1. ábra: Mentor ${ }^{\mathrm{TM}}$ kézterápiás eszköz
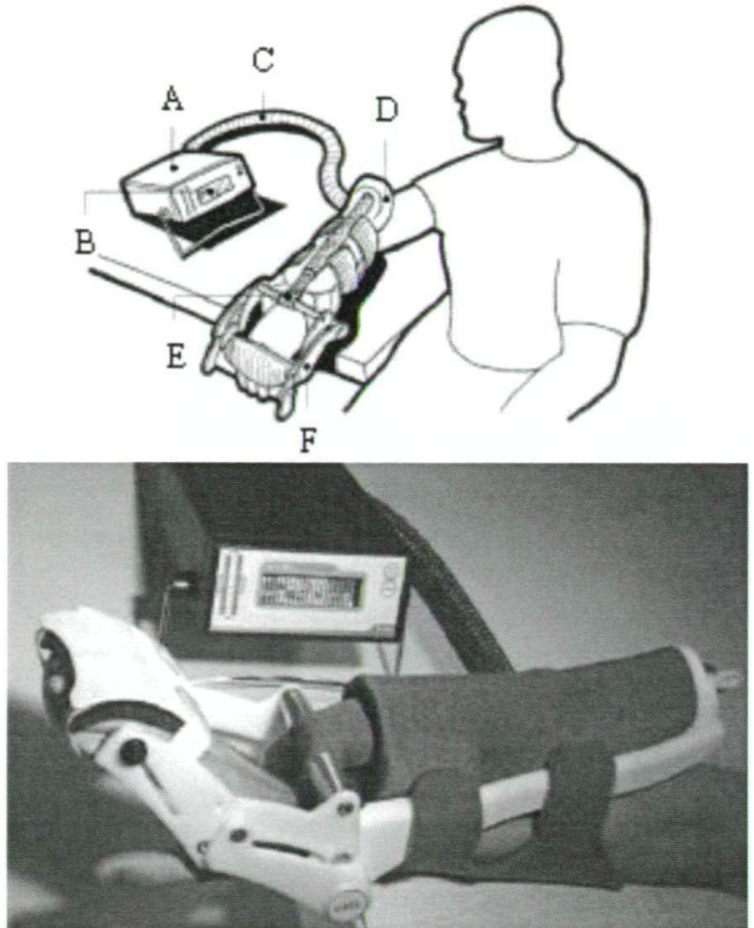

Jelmagyarázat: A - müködtető egység, B - kijelző, C - levegőtömlő, D - alkarbefogó, E - PMI, F mozgató mechanizmus

Forrás: Koeneman et al. 2004

Az általunk kidolgozott kézterápiás eszköz két különböző típusú PMI-t tartalmaz: MAS-10-100 (10 mm belső átmérőjü és $100 \mathrm{~mm}$ hosszúságú), valamint DMSP-10-250 (10 mm belső átmérőjü és $250 \mathrm{~mm}$ hosszúságú) (2. ábra). Az előbbi a csukló, míg az utóbbi az ujjak mozgatásáért felel. Mindkét izmot a Festo szabadalmaztatta és gyártja Fluidic Muscle néven.

2. ábra: MAS-10-100 (fent) és DMSP-10-250 (lent) pneumatikus izmok

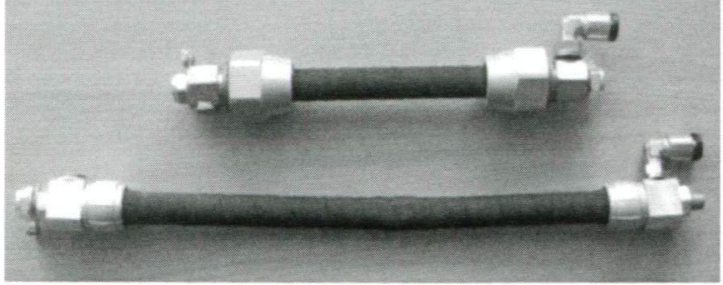

Forrás: A szerzők saját szerkesztése

A PMI-k legfontosabb jellemzőit az erö-kontrakció (erő-relatív elmozdulás) függvénykapcsolat írja le konstans nyomásokon. Ahogy a 3. ábra is bizonyítja, a 
PMI-k által kifejtett erő adott nyomáson az izom összehúzódásával csökken és minimális értéke $(\mathrm{F}=0 \mathrm{~N})$ a kontrakció-maximumnál (minimális hosszúságnál) lép fel.

\section{3. ábra: A 10 mm átmérőjű Fludic Muscle erő-kontrakció jelleggörbéje}

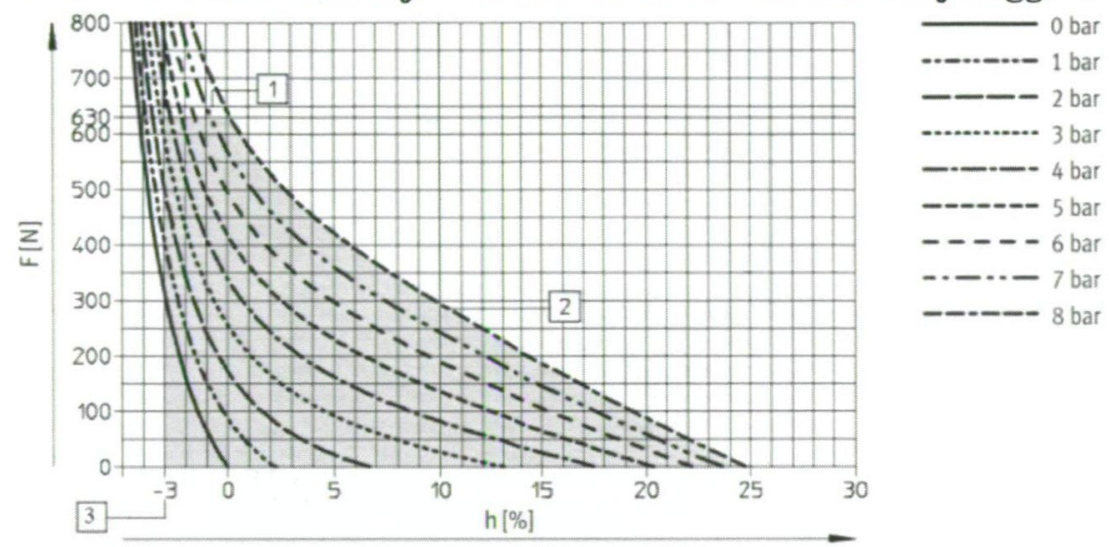

Jelmagyarázat: 1 - maximális erő, 2 - maximális túlnyomás, 3 - maximális megnyújtás, h[\%] kontrakció

Forrás: Festo 2005

A kézterápiás eszköz fö eleme Autodesk Inventorban került megtervezésre. Az ujjak tartását és mozgatását szolgáló elem virtuális modelljét és az elkészített szerkezetét a 4. ábra szemlélteti. 
4. ábra Az ujjak tartásáért és mozgatásáért felelős elem virtuális modellje és elkészült konstrukciója
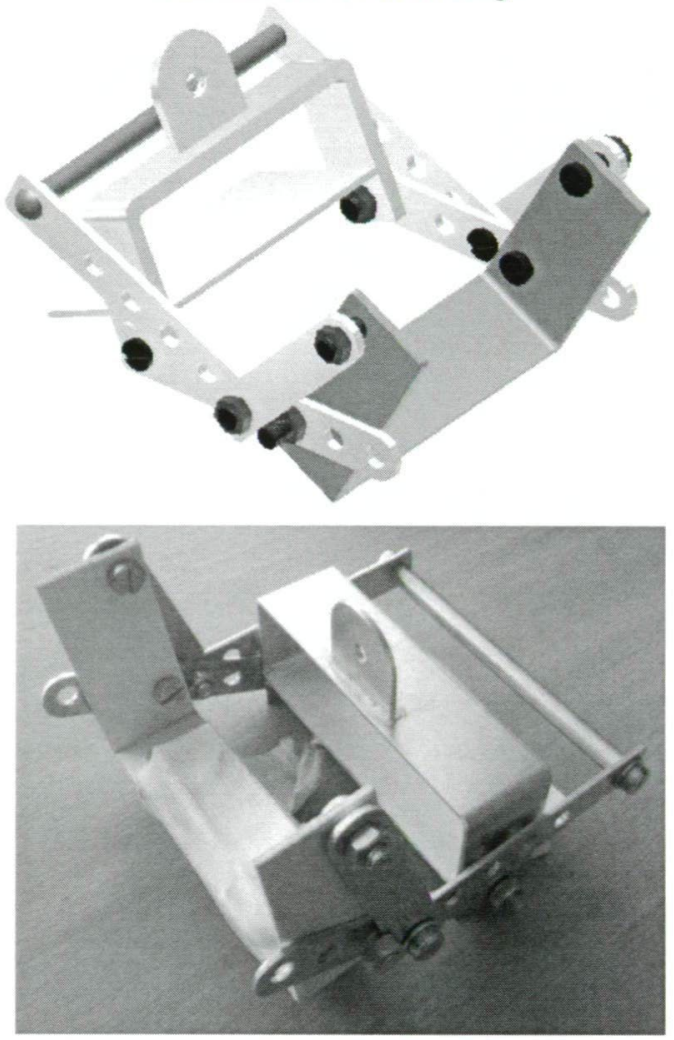

Forrás: A szerzők saját szerkesztése

$\mathrm{Az}$ 5. ábra a teljes kézterápiás készüléket mutatja. Mivel a rögzítő szíjak gumírozott anyagból készültek, ezért különböző méretü kezekre is fel lehet rögzíteni a berendezést. A megépített vázszerkezetbe be kell bújtatni a kézfejet, majd rögzíteni azt a felső, ill. az alsó ujjperceknél. A felső ujjperceknél lévő meggátolja, hogy leessen a kézről az eszköz, az alsó ujjperci rögzités pedig stabilan tartja az ujjakat. A csigát tartalmazó részt a csukló tetejére kell feltenni és a csuklóra felszíjazni. A pneumatikus izmokat a kar felső részére kell rögzíteni a szíjak segítségével.

A terápiás eszköz feladata az ujjak kinyújtása és a kézfej felemelése, ami az izomba juttatott sürített levegö révén valósul meg. A beteg állapotához és sérüléséhez mérten kell beállítani a megfelelő nyomásértéket, ami a kívánt tartományban mozgatja a kezet. 


\section{5. ábra Az elkészített kézterápiás eszköz}

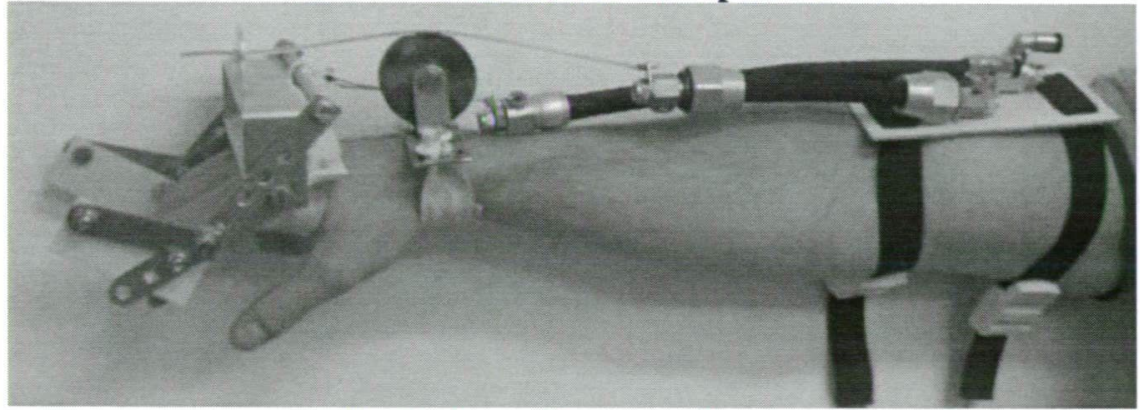

Forrás: A szerzők saját szerkesztése

3. Pneumatikus mesterséges izom által támogatott rehabilitációs eszköz az alsó végtag mozgatására

Az alsó végtag rehabilitációjára szolgáló eszköz egy PMI-t (MAS-20-200, ami 20 $\mathrm{mm}$ belső átmérőjü és $200 \mathrm{~mm}$ hosszúságú) és egy rugót tartalmaz (6. ábra), melyek egyaránt méretezés útján kerültek kiválasztásra. Ahogy a 7. ábrán látható, a nagyobb átmérőjü izom nagyobb erö kifejtésére alkalmas adott nyomásértéken.

\section{6. ábra Méretezés után kiválasztott $20 \mathrm{~mm}$ átmérójü PMI és 2x20x135 mm-es} húzórugó
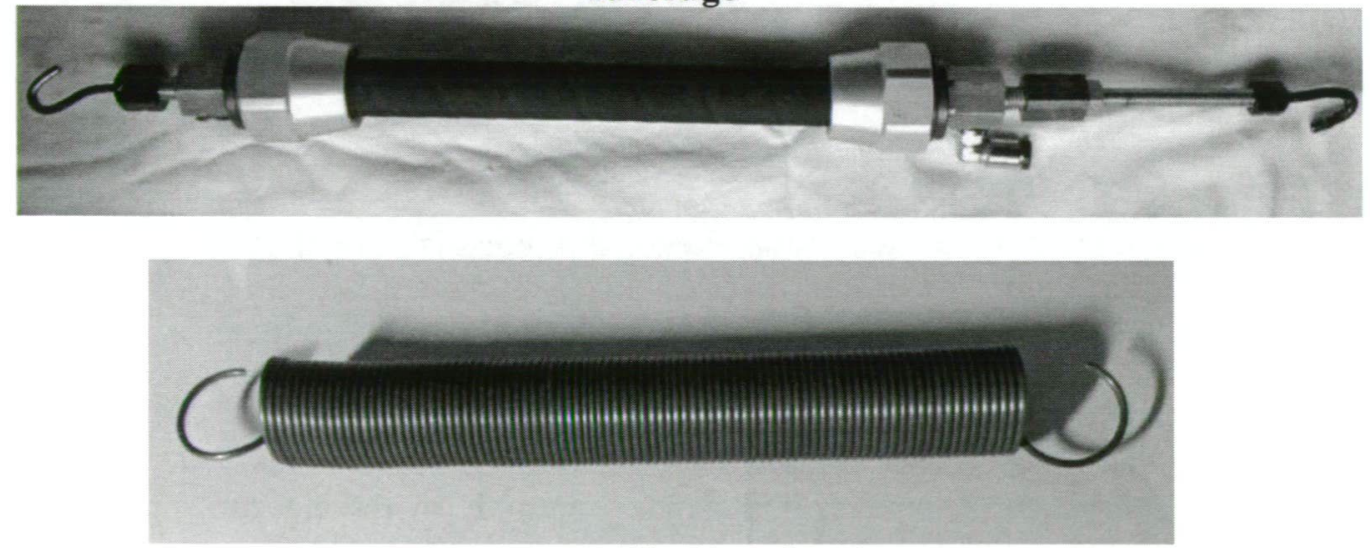

Forrás: A szerzők saját szerkesztése 
7. ábra A 20 mm átmérőjű Fludic Muscle erő-kontrakció jelleggörbéje
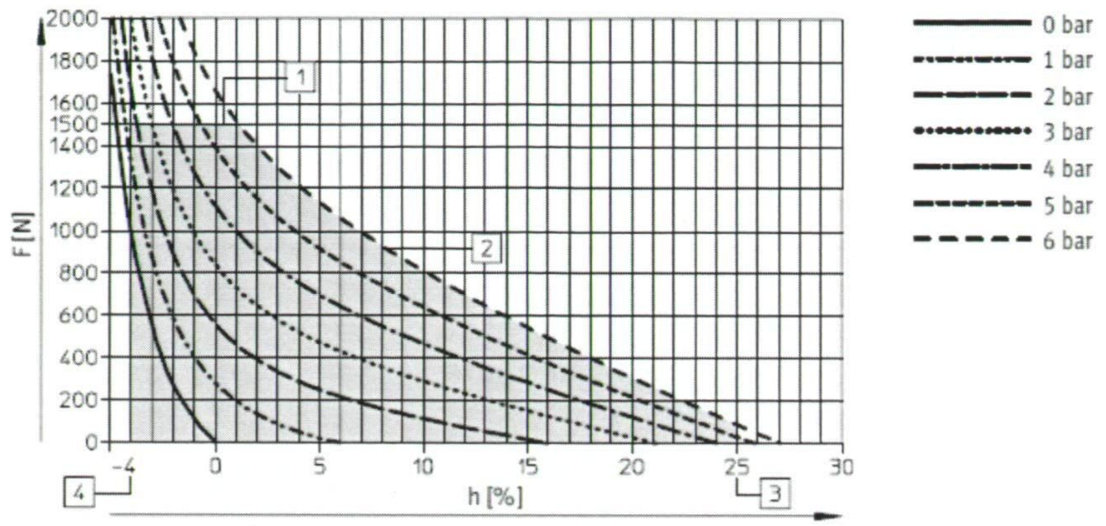

Jelmagyarázat: 1 - maximális erö, 2 - maximális túlnyomás, 3 - maximális megnyújtás, h[\%] kontrakció

Forrás: Festo 2005

A legfontosabb elemek (talp, illetve comb-vádli rögzítő szerkezet) megtervezése itt is Autodesk Inventorban történt (8. ábra).

8. ábra A rehabilitációs eszköz talp és comb-vádli rögzítő szerkezetének virtuális modellje

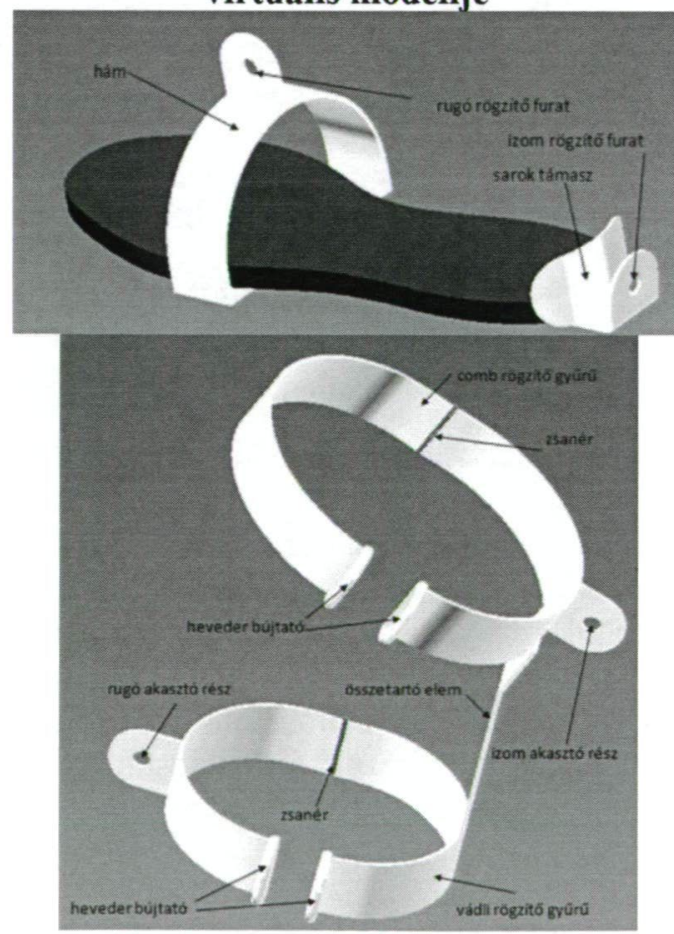

Forrás: A szerzők saját szerkesztése 
Ahogy a 9. ábra szemlélteti, a rugó elöl, míg az izom hátul csatlakozik a talp és a comb-vádli rögzítő szerkezethez. A rehabilitációs eszköz lényege, hogy az izom hátrafeszíti a bokát, míg a rugó ezzel ellentétes erőt fejt ki, mely segítségével visszaállítja a lábfejet az eredeti állapotába. Azért kellett egy izom-rugó párt választani az antagonisztikus müködéshez, mert két izom - hely hiányában - nem tudta volna a lábfejet megfelelő mozgástartományban mozgatni. Az eszköz kényelmes viseletet biztosít a rehabilitáció alatt. Itt is a beteg állapotához és sérüléséhez mérten kell beállítani a megfelelő nyomásértéket, ami a kívánt tartományban mozgatja a lábfejet.

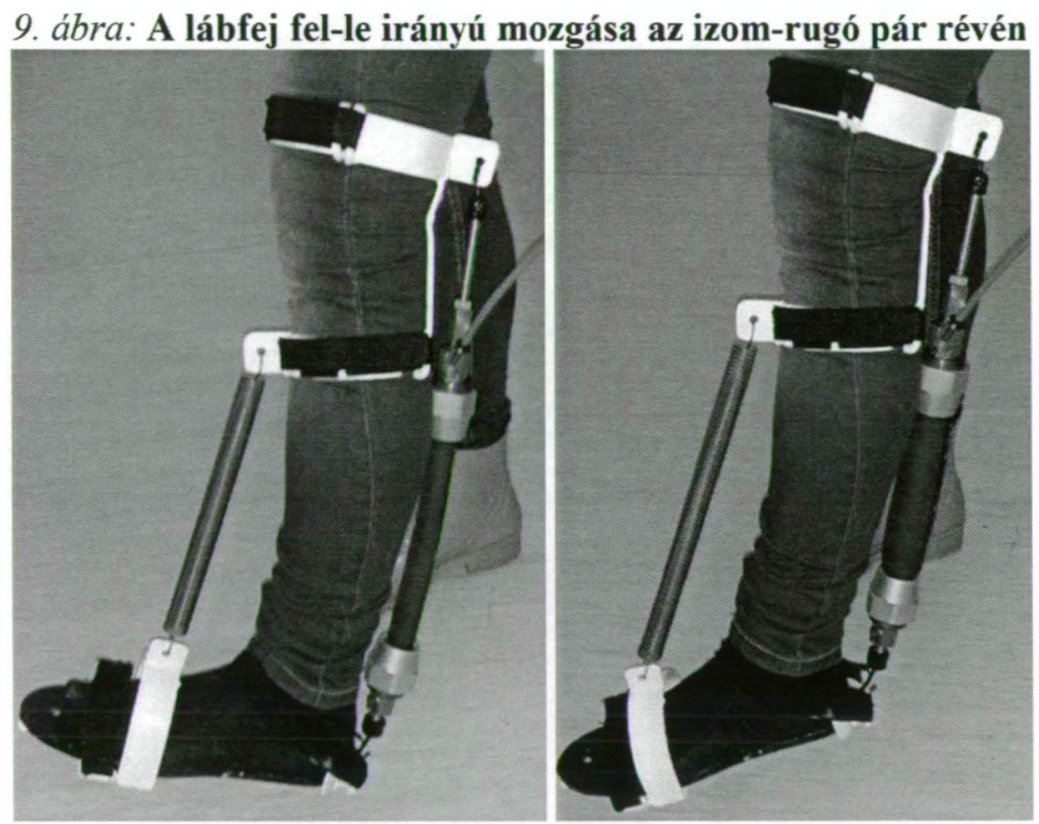

Forrás: A szerzök saját szerkesztése

\section{Következtetések, jövőbeni irányok}

Egyre jobban elötérbe kerülnek olyan robotikus eszközök, melyek mind a klinikákon, mind az otthon elvégzendő, ismétlődő feladatú fizikoterápiás folyamatok elösegítését szolgálják. Statisztikák igazolják, hogy gyógyászati szakemberek hiánya várható, így az ilyen eszközök elterjedése prognosztizálható. E munkánkban azt igazoltuk, hogy a pneumatikus aktuátorok nem csak ipari környezetben, hanem az orvostudomány területén is alkalmazhatók. Ehhez természetesen ki kell egészíteni a mérnöki tervezést és kivitelezést klinikai teszteléssel, ami egyik bemutatott eszköznél sem valósult meg. 


\section{Irodalomjegyzék}

Daerden F. (1999): Conception and Realization of Pleated Artificial Muscles and Their Use as Compliant Actuation Elements. PhD Dissertation. Vrije Universiteit Brussel, Faculteit Toegepaste Wetenschappen Vakgroep Werktuigkunde, 5-33.

Daerden F., Lefeber D. (2002): Pneumatic Artificial Muscles: Actuator for Robotics and Automation. European Joumal of Mechanical and Environmental Engineering. Vol. 47, 10 21.

Festo (2005): Fluidic Muscle DMSP, with Press-fitted Connections, Fluidic Muscle MAS, with Screwed Connections. Termékkatalógus. 39.

Koeneman E. J., Schultz R. S., Wolf S. L., Herring D. E., Koeneman J. B. (2004): A Pneumatic Muscle Hand Therapy Device. Proceedings of the 26th Annual International Conference of the IEEE EMBS, San Francisco, CA, USA, 1-4 September, 2711-2713.

Sárosi J. (2013): Pneumatikus mesterséges izmok müködésének statikus és dinamikus modellezése, nagypontosságí pozicionálása. Doktori $(\mathrm{PhD})$ értekezés. SZIE Műszaki Tudományi Doktori Iskola, Gödöllö, 161.

Sárosi J., Gyeviki J. (2010): Pneumatikus izomelemek alkalmazása gyógyterápiảs eszközökhöz. Jelenkori Társadalmi és Gazdasági Folyamatok. Vol. 5, No. 1-2, 278-282. 